\title{
Study of the diversity of culturable actinomycetes in the North Pacific and Caribbean coasts of Costa Rica
}

\author{
Godofredo Solano $\cdot$ Keilor Rojas-Jiménez • \\ Marcel Jaspars · Giselle Tamayo-Castillo
}

Received: 9 September 2008/Accepted: 25 March 2009/Published online: 14 April 2009

(C) Springer Science+Business Media B.V. 2009

\begin{abstract}
In this study, 137 actinomycetes were isolated from subtidal marine sediments in the North Pacific and Caribbean coasts of Costa Rica. Bioinformatics analysis of the 16S rRNA gene sequences assigned the isolates to 15 families and 21 genera. Streptomyces was the dominant genus while the remaining 20 genera were poorly represented. Nearly $70 \%$ of the phylotypes presented a coastal-restricted distribution whereas the other $30 \%$ were common inhabitants of both shores. The coastal tropical waters of Costa Rica showed a high diversity of actinomycetes, both in terms of the number of species and phylogenetic composition, although significant differences were observed between and within shores.
\end{abstract}

Electronic supplementary material The online version of this article (doi:10.1007/s10482-009-9337-4) contains supplementary material, which is available to authorized users.

G. Solano · M. Jaspars

Chemistry Department, University of Aberdeen, Aberdeen AB24 3UE, UK

G. Solano · K. Rojas-Jiménez · G. Tamayo-Castillo $(\bowtie)$ Unidad Estratégica de Bioprospección,

Instituto Nacional de Biodiversidad,

P.O. Box 22-3100, Santo Domingo de Heredia,

Heredia, Costa Rica

e-mail: gtamayo@inbio.ac.cr

G. Tamayo-Castillo

Escuela de Química, Universidad de Costa Rica,

San Jose, Costa Rica
The observed pattern of species distribution might be the result of several factors including the characteristics of the ecosystems, presence of endemic species and the influence of terrestrial runoff.

Keywords Actinomycetes - Microbial Ecology · Cahuita · Gandoca-Manzanillo · Las Baulas · Cabo Blanco

\section{Introduction}

The actinomycetes comprise a large and diverse group of Gram-positive bacteria that are extensively distributed in several environments. These bacteria are primarily saprophytic and are known to contribute in nutrient turnover, using many available nutrient sources for their development (Williams et al. 1983; Jensen et al. 1991; Stackenbrandt et al. 1997; Mincer et al. 2002). Many actinomycetes are recognized for their metabolic versatility that frequently is accompanied by the production of secondary metabolites of economic importance (Lazzarini et al. 2000; Bull et al. 2000; Bull and Stach 2007). During the last few decades, isolation of actinomycetes has been mainly performed as part of drug discovery programs and has focused on terrestrial sources, but recent efforts turned to marine environments because of the increasing discovery rate of new isolates and promising bioactive compounds from these ecosystems 
(Fenical 1993; Bull et al. 2000; Donadio et al. 2002; Lam 2006). Some actinomycetes have been studied in detail due to their biotechnological importance; however, more comprehensive studies are needed to understand the diversity, distribution and ecology of the large majority of actinomycetes in marine habitats (Stach et al. 2003; Maldonado et al. 2005b; Bull and Stach 2007).

Several statistical tools are currently being developed for describing and comparing microbial communities. For example 16S rRNA gene sequences can be easily assigned to taxonomical hierarchies based on naïve Bayesian classifiers (Wang et al. 2007) or used to perform quantitative analyses of the communities (Martin 2002). Existing tools assign sequences to operational taxonomic units (OTUs) based on genetic distances between sequences which also allow the estimation of ecological parameters such as richness, diversity and degree of similarity between microbial communities (Schloss and Handelsman 2005, 2006). The application of this bioinformatics-based approach is very promising in microbial ecology, particularly for the understanding of organisms such as Actinobacteria in marine environments (Bull et al. 2005).

Costa Rica is a narrow strip of land that connected South America with North America in relatively recent times (approximately 3 million years ago) and thus acts as a natural barrier to the transit of marine forms between the Caribbean and the Pacific Ocean (Rich and Rich 1983). The Caribbean littoral length of the country is comprised of $1,228 \mathrm{~km}$ and is characterized by a regular shape where sandy beaches alternate with rocky promontories. The Pacific littoral is $1,016 \mathrm{~km}$ long and presents several irregularities such as peninsulas, gulfs and bays that contain a number of sandy beaches formed by the accumulation of sediments and distributed by the tides. In general, beaches of the Caribbean and North Pacific show high concentrations of calcium in sediments, which is indicative of the abundant reef structures near these beaches (Cortes 2002; Salazar et al. 2004). In this study a culture-dependent approach was used for isolating actinomycetes from the North Pacific and Caribbean coasts of Costa Rica. The 16S rDNA gene sequences were processed by a series of bioinformatic tools with the aim of describing the composition, diversity and similarity of the actinomycete microbial communities.

\section{Materials and methods}

\section{Sample collection}

This study was conducted in four marine protected areas of Costa Rica under permit number R-0042004-OT-MINAE of the National Ministry of Environment. Two sampling trips were performed in December 2004 to the Caribbean Coast, specifically to Cahuita National Park and Gandoca-Manzanillo National Wildlife Refuge and two further trips in January 2005 to Cabo Blanco Absolute Natural Reserve and Las Baulas Marine National Park in the Pacific. A total of 26 samples were collected, where factors such as distance from the coast, depth and sampling site uniqueness were considered for the collection. The sampling of sea bottom sediments was carried out with a grab sampler while shoreline samples were collected using a small hand-held stainless steel shovel. The samples were put in polyethylene ziplock bags and kept at room temperature in the field, then on ice until transported to laboratory where they were stored at $4^{\circ} \mathrm{C}$. A description of collecting sites is given in Table 1.

Isolation of actinomycetes

Upon arrival at the laboratory, about $1 \mathrm{~g}$ of each sample was taken for actinomycete isolation. Samples were suspended in sterile saline solution $(0.85 \%$ $\mathrm{NaCl})$, treated by thermal shock at $60^{\circ} \mathrm{C}$ for $6 \mathrm{~min}$ and serial diluted to $10^{-3}$. Aliquots $(0.1 \mathrm{ml})$ of each dilution were spread by duplicate on M1 medium plates (Jensen et al. 2005a; prepared with artificial sea water) and glucose-yeast extract medium (Godon and Mihm 1962; prepared with distilled water) amended with nalidixic acid $(10 \mathrm{mg} / \mathrm{ml})$ and nystatin $(50 \mathrm{mg} /$ $\mathrm{ml}$ ). Plates were incubated at room temperature up to six weeks and checked regularly for the emergence of presumptive actinobacteria. New actinomycetes were subcultured onto new M1 or ISP2 (Shirling and Gottlieb 1966) plates supplemented with the above antibiotics. Isolates were compared in their colony and morphological characteristics to select no more than two representatives of the redundant colonies present in each sediment. A total of 137 presumptive actinomycete strains were obtained, for a mean isolation rate of 5.26 strains per sample. Each microorganism was included into a database with 
Table 1 Description of the sampling sites

\begin{tabular}{|c|c|c|c|c|}
\hline $\begin{array}{l}\text { Protected } \\
\text { area }\end{array}$ & Coast & Collecting site description & $\begin{array}{l}\text { Sampling } \\
\text { depth }(m)\end{array}$ & Location \\
\hline $\begin{array}{l}\text { Gandoca- } \\
\text { Manzanillo }\end{array}$ & Caribbean & $\begin{array}{l}\text { Open sea shallow waters located nearby fringing reefs, } \\
\text { patch reefs, and carbonate banks and algal ridges. } \\
\text { Sediments were dark and sandy }\end{array}$ & -10 to -6 & $9^{\circ} 37^{\prime} 10^{\prime \prime} \mathrm{N} 82^{\circ} 36^{\prime} 59^{\prime \prime} \mathrm{W}$ \\
\hline Cahuita & Caribbean & $\begin{array}{l}\text { The largest fringing reef in Costa Rica consisting of } \\
\text { three barriers also presents patch reefs and carbonate } \\
\text { banks. Sediments were coralline sandy. Fine sands } \\
\text { from the beach were sampled as well }\end{array}$ & -17 to 0 & $9^{\circ} 45^{\prime} 44^{\prime \prime} \mathrm{N} 82^{\circ} 49^{\prime} 3^{\prime \prime} \mathrm{W}$ \\
\hline Cabo Blanco & North Pacific & $\begin{array}{l}\text { Open sea shallow waters located neary patch reefs with } \\
\text { coarse sandy sediments of coralline origin. Coarse } \\
\text { sands from the beach were sampled as well }\end{array}$ & -20 to 0 & $9^{\circ} 33^{\prime} 48^{\prime \prime} \mathrm{N} 85^{\circ} 5^{\prime} 4^{\prime \prime} \mathrm{W}$ \\
\hline Las Baulas & North Pacific & $\begin{array}{l}\text { Open sea shallow waters located in front of the mouth } \\
\text { of the Tamarindo estuary. Fine sandy sediments }\end{array}$ & -20 to 0 & $10^{\circ} 18^{\prime} 5^{\prime \prime} \mathrm{N} 85^{\circ} 51^{\prime} 16^{\prime \prime} \mathrm{W}$ \\
\hline
\end{tabular}

associated information such as morphological descriptions, date of collection and date of isolation.

DNA manipulations

The Actinobacteria were grown in liquid ISP2 medium (Atlas 1993) at $25^{\circ} \mathrm{C}$ for 8-15 days with constant shaking at $150 \mathrm{rpm}$. Genomic DNA from actinomycete strains was isolated using the Gen Elute $^{\mathrm{TM}}$ Bacterial DNA Extraction Kit (SigmaAldrich Co., MO, USA) following the manufacturer's instructions. The 16S rRNA gene was PCR amplified from the total DNA extracts using primers $27 \mathrm{f}$ and 1,525r (Lane 1991). The reactions were performed on a GeneAmp PCR system 9700 (Applied Biosystems, $\mathrm{CA}, \mathrm{USA}$ ) at the following temperature program: $95^{\circ} \mathrm{C}$ for $10 \mathrm{~min}$ followed by 35 cycles of $94^{\circ} \mathrm{C}$ for $1 \mathrm{~min}, 52^{\circ} \mathrm{C}$ for $1 \mathrm{~min}$ and $72^{\circ} \mathrm{C}$ for $1 \mathrm{~min}$ and $10 \mathrm{~min}$ extension at $72^{\circ} \mathrm{C}$. The PCR products were purified using the Gen Elute ${ }^{\mathrm{TM}}$ PCR Clean-up Kit (SigmaAldrich Co., MO, USA) according to manufacturer's protocols. Sequencing was performed at the sequencing facility of the Dana Farber Cancer Institute at the University of Harvard, Boston, Massachusetts, using the same PCR primers. The primer sequences of the molecular marker were carefully compared to the corresponding chromatogram and then contiged with the program BioEdit (Hall 1999).

\section{Phylogenetic classification}

The set of 137 sequences, 64 from the Pacific and 73 from the Caribbean, was compared against the
Genbank using the BLAST tool (Altschul et al. 1997) and against the Ribosomal Database Project II using the Classifier tool (http://rdp.cme.msu.edu). The latter assigned the $16 \mathrm{~S}$ rRNA gene sequences to a taxonomical hierarchy based on a naïve Bayesian rRNA classifier with a $95 \%$ confidence interval (Wang et al. 2007). The number of sequences belonging to the major phylogenetic groups was recorded.

\section{Ecological analyses}

The sequence set was aligned using the Infernal secondary-structure based aligner implemented in the RDPII page (Cole et al. 2009) and optimized by hand with BioEdit. The alignment created was processed with DNADIST program of PHYLIP (http://evolution. genetics.washington.edu) to generate a distance matrix, which was used as an input file for DOTUR (http://www.plantpath.wisc.edu). This program grouped the sequences into OTUs according to different sequence similarity cutoffs, which allow the estimation of the community composition regardless of the abundance effect (Schloss and Handelsman 2005). In this study, we used the standard $97 \%$ sequence similarity to distinguish between different bacterial species where two sequences with an identity greater than $97 \%$ were assigned to the same OTU and thus to the same species (Stackebrandt and Goebel 1994). Once DOTUR assigned sequences to OTUs, it was possible to calculate the number of OTUs observed in the collecting sites (relative richness) and the predicted number of OTUs that might exist in each ecosystem (expected richness), based on the bias-corrected 
Chao1 estimator (Chao 1984; Chao and Lee 1992). DOTUR was also used to calculated the Shannon index, a very useful tool for comparing the diversity between communities, and the Simpson index, that shows the likelihood that two individuals taken at random from a community belong to the same species.

We constructed a phylogenetic tree with all the sequences from the two actinobacterial communities with the program MEGA 4.0 (Kumar et al. 2008) using the neighbor joining method and applying a TamuraNei distance-correction (Saitou and Nei 1984). The generated phylogenetic tree and an additional file describing each sequence with the corresponding coast of origin were used as inputs for running the UniFrac web tool (http://bmf2.colorado.edu/unifrac/index.psp) in order to determine statistical differences between communities according to the UniFrac significance test (Lozupone and Knight 2005) and the P test of significance (Martin 2002). This program computes the phylogenetic distance between the sequence sets as the fraction of the branch length of the tree that leads to descendants from either one site or the other (Lozupone and Knight 2005; Lozupone et al. 2006). The similarity in the actinomycete composition between communities was estimated with SONS (http://www. plantpath.wisc.edu/fac/joh/sons.html). This program used as primary input the "*.list" output file from DOTUR and a file containing each sequence identifier with its assigned community of origin. It was possible to estimate the fraction of shared sequences between communities, the fraction of shared OTUs and the overall community similarity (Jaccard's estimator), by accounting for the abundance distributions of OTUs that were either endemic to one site or shared by the two communities (Schloss and Handelsman 2006).

\section{Results}

Taxonomic composition

Results of the comparison of the 16S rRNA gene sequences against the RDP II database assigned the isolates to 15 families of actinomycetes and 21 genera (Fig. 1). From these, six genera were isolated from both the Pacific and the Caribbean (Streptomyces, Nocardia, Nonomuraea, Rhodococcus, Saccharopolyspora and Gordonia) while 8 genera were found exclusively in the Pacific and 7 exclusively in the Caribbean. When

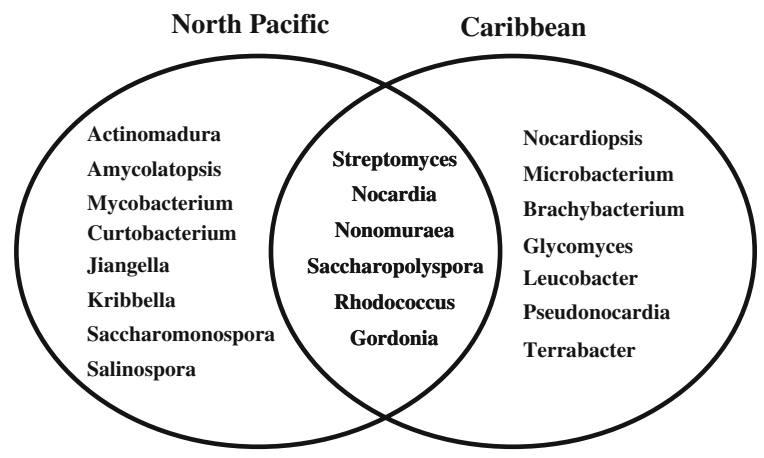

Fig. 1 Distribution of genera per site of isolation for the 137 actinomycetes analyzed in this study

analyzing the diversity within the specific sites, Las Baulas and Cabo Blanco located at the North Pacific contained 10 and 8 actinomycete genera, respectively. At the Caribbean, Cahuita and Gandoca-Manzanillo harbored 7 and 9 actinomycete genera. A remarkable feature of this data set was that Streptomyces was the dominant genus recovered from both shores, comprising nearly two-thirds $(64.5 \%)$ of the total of isolates. The other 20 genera were poorly represented, accounting for the remaining $35.5 \%$ of the isolates.

Species richness and diversity

The analysis of the ecological estimators showed that 44 phylotypes of actinomycetes were recovered from the sampling sites at the North Pacific and the Caribbean of Costa Rica (Table 2). Also, the estimation of the number of species predicted according to the Chao1 estimator indicated that both communities combined might harbor a mean of 67 species $(95 \%$ CI: 52-111). When calculated separately by coast, the program determined that each of the sites presented 22 OTUs, although not necessarily corresponding to the same species. The total number of species expected for the North Pacific community was 37 species (95\% CI: 25-86) and 33 species for the Caribbean (95\% CI: 24-63). The diversity of the actinomycete collection, according to the Simpson index, was 0.09 . This represents a probability of $9 \%$ that two individuals taken at random from the collection belong to the same species (Table 2). However, when Simpson index was estimated for each coast, results showed a value of 0.07 for the Pacific and 0.15 for the Caribbean, indicating that the likelihood of finding identical species in the Pacific 
Table 2 Main ecological estimators calculated for the overall collection, the North Pacific and the Caribbean samples

\begin{tabular}{lcll}
\hline & $\begin{array}{l}\text { Overall } \\
\text { collection }\end{array}$ & $\begin{array}{l}\text { North Pacific } \\
\text { samples }\end{array}$ & $\begin{array}{l}\text { Caribbean } \\
\text { samples }\end{array}$ \\
\hline OTUs observed & 44 & 22 & 22 \\
OTUs expected & 67 & 37 & 33 \\
Simpson & 0.09 & 0.07 & 0.15 \\
Shannon & 3.33 & 2.75 & 2.39 \\
\hline
\end{tabular}

Data were estimated by DOTUR program using a $3 \%$ distance cutoff

samples is lower than in the Caribbean samples and hence, an indirect measurement of higher diversity in the Pacific. The estimation of the diversity using the Shannon index, for the overall collection was 3.33. When estimated separately the North Pacific coast showed a value of 2.75 and the collection from the Caribbean a value of 2.39. This index is the most widely used in ecology, where values typically fall between 1.5 and 4 , with higher values representing higher diversity.

Comparison of the actinomycete communities

The comparison of the actinomycete composition between the North Pacific and Caribbean coast was computed with UniFrac, based on phylogenetic information. Results of this comparison using both the UniFrac and the P significance tests revealed that species composition of either coast differed significantly from the other $(P<0.01 ; n=137)$. This was consistent with results of the similarity analyses determined with SONS showing that the percentage of phylotypes shared between the communities was $33-35 \%$, at a distance level of $3 \%$. The overall Jaccard's similarity between the North Pacific and Caribbean collections was 0.20 , which is the ratio in the number of species in each community to the total number of species. When comparing within Caribbean sites, results showed that $62 \%$ of the isolates in Gandoca-Manzanillo and $57 \%$ in Cahuita were common to both places. However, the number of OTUs shared between these sites was close to $31 \%$. Furthermore, the Jaccard's estimation of the similarity between these communities was $18 \%$. The comparison between Cabo Blanco and Las Baulas in the North Pacific showed that a high percentage of the sequences and OTUs were common to both ecosystems (Table 3).

\section{Discussion}

In this study we obtained 137 actinomycete isolates from four sampling sites located in the North Pacific and Caribbean waters of Costa Rica. Several bioinformatics tools were used to analyze 16S rRNA gene sequences and to determine species composition, diversity and other ecological parameters. Taxonomic composition analysis of the collection shows that the number of genera isolated in this study is comparable or even higher to that found in other culturedependent studies (Mincer et al. 2002; Maldonado et al. 2005a, b; Jensen et al. 2005b; Bredholdt et al. 2007). In addition, it was remarkable that 15 out of the 30 families described for the order Actinomycetales were represented in the collection (Stackenbrandt et al. 1997). This suggests that, despite the modest number of isolates, the coastal sediments sampled in these tropical waters might be considered as rich sources of Actinobacteria, both in terms of the number of species and the phylogenetic composition.

The most abundant genus in this collection was Streptomyces, comprising nearly two-thirds of the isolates, while the other 20 genera remained less well

Table 3 Main statistical estimators of the comparisons between the communities of marine actinomycete isolates

\begin{tabular}{|c|c|c|c|c|c|c|}
\hline \multirow[t]{2}{*}{ Communities compared } & \multirow[t]{2}{*}{$n$} & \multicolumn{2}{|c|}{ Shared sequences } & \multicolumn{2}{|c|}{ Shared OTUs } & \multirow[t]{2}{*}{ Jaccard's similarity } \\
\hline & & Comm. 1 & Comm. 2 & Comm. 1 & Comm. 2 & \\
\hline Caribbean-North Pacific & 137 & 0.63 & 0.31 & 0.35 & 0.33 & 0.20 \\
\hline Gandoca-Cahuita & 73 & 0.62 & 0.57 & 0.31 & 0.31 & 0.18 \\
\hline Cabo Blanco-Baulas & 64 & 0.82 & 0.67 & 0.64 & 0.53 & 0.41 \\
\hline
\end{tabular}

Data were calculated with SONS program using a $3 \%$ distance cutoff 
represented. Interestingly, genera such as Micromonospora and Salinispora that have been reported as dominant in other marine ecosystems were scarcely detected in this study (Magarvey et al. 2004: Maldonado et al. 2005a: Bull et al. 2005: Jensen et al. 2005a, b). This outcome might be explained by differences in the sample pre-treatment used and media isolation employed, which may account for the high presence of Streptomyces and the absence of Micronospora and Salinospora. When analyzing the geographic species distribution using both phylogenetic-based and distance-based approaches, it was observed that nearly $70 \%$ of the genera presented an apparent coastal-restricted distribution while the remaining $30 \%$ were detected in both the North Pacific and Caribbean. However, these results should be treated with caution since lack of recovery cannot be assumed as absence of the organism in one site. Our results raise the question of why some species are found on both coasts and others just on one. Although we cannot propose a clear explanation for this observation, one possible reason could be that species that are shared in Pacific and Caribbean shores existed before the Central American Isthmus closed the connection between the oceanic waters ca. 3 million years ago (Rich and Rich 1983). Another possible explanation is that these species might present a ubiquitous distribution (Maldonado et al. 2005b; Lam 2006). The reasons for the differences in the actinomycetes composition between populations in the North Pacific and the Caribbean are complex and might be the result of the interaction of several factors. Firstly, ecosystem characteristics: the inherent physical, chemical and biological characteristics of the Caribbean Sea and Pacific Ocean could influence the life forms that developed on their respective shores. The ecosystems at the sampling sites in the Caribbean were quite different from the sites in the North Pacific. For example, in the Caribbean, both Cahuita and Gandoca-Manzanillo are characterized by the presence of fringing reefs, patch reefs and carbonate banks although they differ in size, shape, diversity of species, and terrestrial runoff influence (Cortes 2002). In the Pacific, the sampling sites in Cabo Blanco presented mainly patch reefs with other coral species and Las Baulas comprised a particular ecosystem located at the mouth of the Tamarindo estuary, where salinity, organic matter content and the species developed differ from the other marine sites sampled. Another physical factor that could have an effect on species distribution, particularly in the North Pacific, was the upwelling, which is a wind-driven effect that replaces the warmer surface waters with subsurface nutrientrich waters. This effect occurred precisely during the sampling period (Brenes et al. 2002), and could provoke the homogenization of sediment-living bacteria and the circulation between locations as judged by the higher percentage of sequences and OTUs shared between the two sites sampled in this coast.

The second major influence could be the presence of endemic species. The amount of singletons detected in all the sites suggests that functional changes could be occurring in these bacteria in order to adapt to the specific ecological niches, which might be accompanied with the development of speciation processes. Finally, the influence of terrestrial runoff may be important: the sampling sites are directly influenced by rivers that bring sediments and consequently terrestrial actinomycetes into the coasts, i.e. those in the Caribbean, Cahuita and Manzanillo are affected by sediment runoff from the La Estrella and Sixaola watersheds, respectively. In the Pacific, Las Baulas is influenced by the Tamarindo mangrove estuary. Thus, at this point of the study is difficult to establish whether the isolates are truly "marine" or have terrestrial origin with possible halo tolerance characteristics.

The ecological estimators determined in this study were consistent in suggesting that these tropical waters showed a high diversity of actinomycetes, both in terms of the number of species and the species composition. However, significant differences in the phylogenetic distribution were observed between and within the North Pacific and the Caribbean shores. When comparing the Jaccard's similarity between sites, the estimation was consistent with previous results at showing that nearly one-third of the total number of OTUs was found in both shores. When analyzed separately within shores, the results suggest that species composition in Cahuita and GandocaManzanillo is quite different, most likely due to the strong influence of the La Estrella and Sixaola rivers and the existence of a local current, perpendicular to the coast, that might limit microorganism exchange between these sites. In the Pacific, Las Baulas and Cabo Blanco presented a more homogeneous composition that could be the result of the mixing effect of the wind-driven upwelling as mentioned above. 
To our knowledge, this is the first report of the isolation and ecological characterization of actinomycetes from the North Pacific and Caribbean coasts of Costa Rica. We determined that these tropical waters are rich in terms of composition and that important differences can be observed between and within shores. Further studies are needed to elucidate the marine or terrestrial origin of the isolates and the role they play in their respective ecosystems.

Acknowledgments We would like to thank Luis Acosta from INBio, the Center of Marine Research (CIMAR) of the University of Costa Rica and Michael Goodfellow from the School of Biology, University of Newcastle for their contribution along the development of this project. This research was funded by the College of Physical Sciences of the University of Aberdeen and by the NIH grant (U01 TW007404-01 ICBG). MJ is the recipient of a BBSRC Research Development Fellowship. We thank the Ministry of Environment and Energy, Costa Rica for the collection permit (R-004-2004-OT-MINAE).

\section{References}

Altschul SF, Madden TL, Schäffer AA, Zhang J, Zhang Z, Miller W, Lipman DJ (1997) Gapped BLAST and PSIBLAST: a new generation of protein database search programs. Nucleic Acids Res 25:3389-3402. doi:10.1093/ nar/25.17.3389

Atlas RM (1993) Handbook of microbial media L.C. Parks (ed) CRC Press, London

Bredholdt H, Galatenko O, Engelhardt K, Fjærvik E, Terekhova L, Zotchev S (2007) Rare actinomycete bacteria from the shallow water sediments of the Trondheim fjord, Norway: isolation, diversity and biological activity. Environ Microbiol 11:2756-2764. doi:10.1111/j.14622920.2007.01387.x

Brenes CL, Coen JE, Chelton DB, Enfields BB, Leon S, Ballestero D (2002) Wind driven upwelling in the Gulf of Nicoya, Costa Rica. Int J Remote Sens 5:1127-1133

Bull AT, Stach JEM (2007) Marine actinobacteria: new opportunities for natural product search and discovery. Trends Microbiol 11:491-499. doi:10.1016/j.tim.2007.10.004

Bull AT, Ward AC, Goodfellow M (2000) Search and discovery strategies for biotechnology: the paradigm shift. Microbiol Mol Biol Rev 64:573-606. doi:10.1128/ MMBR.64.3.573-606.2000

Bull AT, Stach JEM, Ward AC, Goodfellow M (2005) Marine actinobacteria: perspectives, challenges, future directions. Antonie Van Leeuwenhoek 87:65-79. doi:10.1007/s10482004-6562-8

Chao A (1984) Non-parametric estimation of the number of classes in a population. Scand J Stat 11:265-270

Chao A, Lee SM (1992) Estimating the number of classes via sample coverage. J Am Stat Assoc 87:210-217. doi: $10.2307 / 2290471$
Cole JR, Wang Q, Cardenas E, Fish J, Chai B, Farris RJ, Kulam-Syed-Mohideen AS, McGarrell DM, Marsh T, Garrity GM, Tiedje JM (2009) The ribosomal database project: improved alignments and new tools for rRNA analysis. Nucleic Acids Res 37:141-145. doi:10.1093/nar/ gkn879

Cortes J (2002) The coral reefs of Costa Rica's Caribbean Coast. Instituto Nacional de Biodiversidad, Heredia, Costa Rica, p 140

Donadio S, Monciardini P, Alduina R, Mazza P, Chiocchini C, Cavaletti L, Sosio M, Puglia AM (2002) Microbial technologies for the discovery of novel bioactive metabolites. J Biotechnol 99:187-198. doi:10.1016/S0168-1656(02) 00209-2

Fenical W (1993) Chemical studies of marine bacteria: developing a new resource. Chem Rev 93:1673-1683. doi:10.1021/cr00021a001

Godon RE, Mihm JM (1962) Identification of Nocardia caviae (Erikson) nov. comb. Ann N Y Acad Sci 98:628-636. doi:10.1111/j.1749-6632.1962.tb30585.x

Hall TA (1999) BioEdit: a user-friendly biological sequence alignment editor and analysis program for Windows 95/ 98/NT. Nucleic Acids Symp Ser 41:95-98

Jensen PR, Dwight R, Fenical W (1991) Distribution of actinomycetes in near-shore tropical marine sediments. Appl Environ Microbiol 57:1102-1108

Jensen PR, Gontang E, Mafnas C, Mincer TJ, Fenical W (2005a) Culturable marine actinomycete diversity from tropical Pacific Ocean sediments. Environ Microbiol 7:1039-1048. doi:10.1111/j.1462-2920.2005.00785.x

Jensen PR, Mincer TJ, Williams PG, Fenical W (2005b) Marine actinomycete diversity and natural product discovery. Antonie Van Leeuwenhoek 87:43-48. doi:10.1007/s10482004-6540-1

Kumar S, Dudley J, Nei M, Tamura K (2008) MEGA: a biologist-centric software for evolutionary analysis of DNA and protein sequences. Brief Bioinform 9:299-306. doi:10.1093/bib/bbn017

Lam KS (2006) Discovery of novel metabolites from marine actinomycetes. Curr Opin Microbiol 9:245-251. doi: 10.1016/j.mib.2006.03.004

Lane DJ (1991) 16S/23S rRNA sequencing. In: Stachebrandt E, Goodfellow M (eds) Nucleic acid techniques in bacterial systematics. Wiley, Chichester, NY

Lazzarini A, Cavaletti L, Toppo G, Marinelli F (2000) Rare genera of actinomycetes as potential producers of new antibiotics. Antonie Van Leeuwenhoek 78:399-405. doi:10.1023/A:1010287600557

Lozupone C, Knight R (2005) UniFrac: a new phylogenetic method for comparing microbial communities. Appl Environ Microbiol 71:8228-8235. doi:10.1128/AEM.71. 12.8228-8235.2005

Lozupone C, Hamady M, Knight R (2006) UniFrac_an online tool for comparing microbial community diversity in a phylogenetic context. BMC Bioinformatics 7:371. doi:10.1186/1471-2105-7-371

Magarvey NA, Keller JM, Bernan V, Dworkin M, Sherman DH (2004) Isolation and characterization of novel marinederived Actinomycete taxa rich in bioactive metabolites. Appl Environ Microbiol 70:7520-7529. doi:10.1128/ AEM.70.12.7520-7529.2004 
Maldonado LA, Fenical W, Jensen PR, Kauffman CA, Mincer TJ, Ward AC (2005a) Salinispora arenicola gen nov., and Salinispora tropica sp. nov., obligate marine actinomycetes belonging to the family Micromonosporaceae. Int $\mathbf{J}$ Syst Evol Microbiol 55:1759-1766. doi:10.1099/ijs.0. 63625-0

Maldonado LA, Stach JE, Pathom-aree W, Ward AC, Bull AT, Goodfellow M (2005b) Diversity of cultivable Actinobacteria in geographically widespread marine sediments. Antonie Van Leeuwenhoek 87:11-18. doi:10.1007/ s10482-004-6525-0

Martin A (2002) Phylogenetic approaches for describing and comparing the diversity of microbial communities. Appl Environ Microbiol 68:3673-3682. doi:10.1128/AEM.68. 8.3673-3682.2002

Mincer TJ, Jensen PR, Kauffman CA, Fenical W (2002) Widespread and persistent populations of a major new marine actinomycete taxon in ocean sediments. Appl Environ Microbiol 68:5005-5011. doi:10.1128/AEM.68. 10.5005-5011.2002

Rich DV, Rich TH (1983) The Central American dispersal route: biotic history and peleogeography. Costa Rican Natural History. Ed. Daniel H. Janzen. The University of Chicago Press, In, pp 12-34

Saitou N, Nei M (1984) The neighbour-joining method: a new method for reconstructing phylogenetic trees. Mol Biol Evol 4:406-425

Salazar A, Lizano O, Alfaro E (2004) Composición de sedimentos en las zonas costeras de Costa Rica utilizando Florescencia de Rayos-X (FRX). Rev Biol Trop 52:61-75
Schloss PD, Handelsman J (2005) Introducing DOTUR, a computer program for defining operational taxonomic units and estimating species richness. Appl Environ Microbiol 71:1501-1506. doi:10.1128/AEM.71.3.15011506.2005

Schloss PD, Handelsman J (2006) Introducing SONS, a tool for operational taxonomic unit-based comparisons of microbial community membership and structures. Appl Environ Microbiol 72:6773-6779. doi:10.1128/AEM.00474-06

Shirling EB, Gottlieb D (1966) Methods for characterization of Streptomyces species. Int J Syst Bacteriol 16:313-340

Stach JEM, Maldonado LA, Ward AC, Goodfellow M, Bull AT (2003) New primers specific for Actinobacteria: application to marine and terrestrial environments. Environ Microbiol 5:828-841. doi:10.1046/j.1462-2920.2003.00483.x

Stackebrandt E, Goebel BM (1994) Taxonomic note: a place for DNA-DNA reassociation and $16 \mathrm{~S}$ rDNA sequence analysis in the present species definition in bacteriology. Int J Syst Bacteriol 44:846-849

Stackenbrandt E, Rainey FA, Ward-Rainey NL (1997) Proposal for a new hierarchic classification system, Actinobacteria classis nov. Int J Syst Bacteriol 47:479-491

Wang Q, Garrity GM, Tiedje JM, Cole JR (2007) Naïve Bayesian classifier for rapid assignment of rRNA sequences into the new bacterial taxonomy. Appl Environ Microbiol 73:5261-5267. doi:10.1128/AEM.00062-07

Williams ST, Lanning S, Wellington EMH (1983) Ecology of actinomycetes. In: Goodfellow M, Mordarski M, Williams ST (eds) The biology of actinomycetes. Academic Press, London, UK, pp 481-528 